\title{
Evaluation of Navigational Aspects of Moodle
}

\author{
Raheela Arshad, Awais Majeed* \\ Department of Software Engineering \\ Bahria University \\ Islamabad, Pakistan
}

\author{
Hammad Afzal \\ Department of Computer Software \\ Engineering \\ National University of Sciences \& \\ Technology (NUST) \\ Islamabad, Pakistan
}

\author{
Muhammad Muzammal, Arif ur \\ Rahman \\ Department of Computer Science \\ Bahria University \\ Islamabad, Pakistan
}

\begin{abstract}
Learning Management System (LMS) is an effective platform for communication and collaboration among teachers and students to enhance learning. These LMSs are now widely used in both conventional and virtual and distance learning paradigms. These LMSs have various limitations as identified in the existing literature, including poor learning content, use of appropriate technology and usability issues. Poor usability leads to the distraction of users. Literature covers many aspects of usability evaluation of LMS. However, there is less focus on navigational issues. Poor navigational can lead to disorientation and cognitive overload of the users of any Web application. For this reason, we have proposed a navigational evaluation framework to evaluate the navigational structure of the LMS. We have applied this framework to evaluate the navigational structure of Moodle. We conducted a survey among students and teachers of two leading universities in Pakistan, where Moodle is in use. This work summarizes the survey results and proposes guidelines to improve the usability of Moodle based on the feedback received from its users.
\end{abstract}

Keywords-e-Learning; Navigational Evaluation Framework; Learning management system (LMS); Moodle; Usability

\section{INTRODUCTION}

Rapid increase in technology provided educational institutions the opportunity to use Internet as a communication source for instructions. The notions used in technology-based learning are now becoming significant with e-learning and have become a vital medium for educational organizations for an efficient provision of learning material [1]. For e-learning environments, it is important that they should be designed and evaluated in an academically efficacious manner by taking into consideration both pedagogical and usability concerns [2]. A reliable foundation of the e-learning platform is learning management system (LMS) that complies with educational standards and best practices endorsed by experienced educationists [3]. However, despite the prevalent use of LMSs, the critical examination of their usability is a relatively new area of research [4]. Studies [2] [5] showed that although there are many other reasons of high distraction in elearning platforms such as inappropriate use of contents and technology, but the key issue is the poor usability of such platforms. Therefore, usability of such applications should be very high. When speaking of usability of LMS, we navigation is a vital factor to be considered and required to be evaluated. A good navigation structure in LMS helps users accomplishing learning activities without spending too much time to learn how to go to the next page [6].
Moreover, new Web design methodologies treat navigation as a separate concern [7]. Still there is no framework for evaluating the effectiveness of the navigation structure of the LMS. Therefore, in this research, we proposed a framework for evaluation of the navigational structure of the LMS. Moodle is selected for the evaluation and through a survey we received feedback on the evaluation framework from users of Moodle in order to validate the factors of the framework as well as to identify the problems in navigation design of Moodle.

Moodle (Modular Object-Oriented Dynamic Learning Environment) is one of the most widely used open source LMS intended to design complete educational principles to support instructors in creating effective online learning groups. Martin Dougiamas founded Moodle as part of his $\mathrm{PhD}$ thesis in 1999 and in 2002 it was released to the public. Design of Moodle is based on constructivism and pedagogical philosophies. Pedagogy is concerned with the strategies of instruction or how best to teach; and constructivism provides an ability for users to share their ideas and experiences to one another [8].

The research questions and hypotheses addressed in this research are:

1) What are the navigational factors that are important in the context of LMS?

2) How efficient is the navigation of Moodle based on the identified factors?

3) Is there a difference between responses received from two universities?

H1: The correlation of ease of navigation experience with satisfaction about navigation design and efficiency of performing the task is significant.

H2: The correlation of seven navigation factors is significant with ease of navigation and satisfaction about navigation design.

The assessment is conducted in two universities in Pakistan using the survey technique. The rest of this study is divided into 5 sections. Section II presents related work. Section III describes the research methodology used in this research. Section IV describes important navigation factors of the proposed framework. Section $V$ provides a detailed insight on results and findings. Finally, section VI presents conclusions and future work. 


\section{RELATED WORK}

\section{A. Usability in the context of LMS}

In case of e-learning platforms, it is not just enough to provide users with such systems that contain extensive features with minimum or no cost at all. Research on Human Computer Interaction (HCI) suggests that the major issue in technology is usability and how easy to use a system is. Usability is a quality attribute as indicated by Jakob Nielsen, a usability expert who brought the concept of Web usability [9]. According to ISO usability is "The extent to which a product can be used by specified users to achieve specified goals with effectiveness, efficiency, and satisfaction in a specified context of use." [10]. Usability of LMS significantly affects the learning, since students' interaction with these systems should result in a successful achievement of learning goals rather to complete a task successfully. Consequently, the interface of LMSs should not distract learners from accomplishing their learning objectives. When these systems are not easy to use, users might spend more time trying to understand how to start interacting with the system, instead of engaging with the actual learning material. Inversini et al. [11] indicated that, in terms of teaching and learning, a usable LMS significantly reduces teacher time spent in setting up and managing the course contents and improves the students learning performance as well as experience. Thus, the LMS should have a simple interface with which teachers and students do not need to be worried about difficult technology and can put concentration on learning contents. Usability comprises many factors; among these navigation is one of the major factors that influence the usability. Nielsen [10] indicated that intuitively organized and easy to navigate Web pages, help users find the required information with ease.

\section{B. Importance of ease of navigation in LMS}

Easy navigation is important in any LMS that enhances the learning activities. Users especially students are from different educational backgrounds and some of them are not proficient in using computers and computer applications. LMS is a Webbased system, and therefore, it can become a barrier to learners who are less proficient with computers. To overcome this obstacle, the LMS should be designed in such a way that it is user friendly and has a well-managed interface with good navigation to help users understand the content quickly [12]. Hence, when designing LMS, ease of navigation should be the top priority because if the course is easy to navigate, the learners will have a better learning experience even if they have no or minimal computer skills. Fluid movement within the LMS, allows users to freely explore entire LMS whereas, poorly designed navigation might hamper user interactions and reduce productivity [13].

Good navigation contributes in self-directed learning and facilities the progress throughout the learning process. Alternatively, difficult navigation creates difficulty for learners to achieve learning outcomes successfully [14]. Also, it is frustrating when users get disoriented while navigating through the LMS. A well-organized LMS enables users to focus on the desired goals.

Without a good navigation provision, students are not able to achieve learning goals because they are not able to know what page they need to go to obtain desired learning materials [6]. Free navigation through LMS permits the learners to create their specific knowledge structures and it is a critical factor in assisting interactivity among them [15]. If LMS does not permit learners to navigate efficiently, then this can become a hurdle for them to be involved as active participants in the learning process. Thus, navigation is an essential part of any LMSs that enhances the learning activities by delivering the learning materials effectively to students.

\section{Moodle's usability evaluation}

In the literature we came across regarding usability evaluation of Moodle, we analysed that the usability of Moodle has been evaluated mostly based on Nielson's heuristics. Further, we investigated some characteristics of usability have been explored such as efficiency, ease of use, effectiveness, and learnability, and few others. We found navigational characteristic has not been explored as a broader usability characteristic. Author in [16] shows the usability of Moodle's registration module and assignment submission module by utilizing the DECIDE framework. Additionally, another similar study [17] evaluated the usability of Moodle different modules by employing questionnaires, task driven and heuristic evaluation techniques and generated qualitative and quantitative data. Beside these data, expert opinions were also given to provide important recommendations for all users to create a more user friendly Moodle. Ivanović et al. [18] explored usability of Moodle in order to reflect the teachers' and students' opinions.

User satisfaction is a factor on which usability may exert influence. Also, to achieve learning goals in e-learning platforms, it is a very crucial aspect to be considered. Thus, in [19] user satisfaction was more focused during usability analysis of Moodle in which students' perceptions were more motivated. In this study navigation acquired very little attention. In another study [20], efficiency and ease of learning of Moodle were analysed in order to reflect the usability. Padayachee et al. [21] conducted a usability comparison based on Nielsen's heuristics for three LMSs including Moodle, DOKEOS, and ATutor. This study explored issues against each heuristic. In this study heuristic "Flexibility and efficiency of use" covered a navigation aspect related to navigation jumps; for quickly performing desired actions. Another similar study [22] conducted a comparative usability evaluation among Moodle, Sakai, and dotLRN. This evaluation was based on Nielsen's heuristics in which five usability experts followed a task-based approach. Strengths and weaknesses against each heuristic were explored in relation to each LMS. The study presented in [23], is an enhancement of previous one, but in this study pattern-based usability analysis was conducted. Patterns were based on Nielson's heuristics, in which authors selected one pattern against each heuristic. The study presented in [24] also used Nielsen's usability heuristics to compare the usability of three LMSs i.e. WebCT, Sakai, and Moodle with perspectives of students. Another study [25] performed usability comparison between two LMSs: Blackboard and Moodle from the viewpoint of students and faculty. The main focus of this study was on efficiency, ease of use, desired functionality, and user interface. The authors of this study concluded that 
Moodle is more efficient and effective than Blackboard LMS. In [26], usability evaluation of Moodle from teachers' and students' perspective was conducted. This evaluation used five usability aspects; efficiency, memorability, errors, satisfaction, and learnability suggested by Nielsen. The previous study is similar to the one presented in [27] that used two additional usability characteristics; operationability and attractiveness, to assess the usability of Moodle. Quality is an important aspect that affects usability as indicated in [28] thus, Oztekin et al. [29] proposed a new approach UseLearn for usability evaluation of e-learning platforms. It incorporates both usability evaluation perspective and quality in e-learning platforms. In this approach navigation achieved a little attention to evaluate usability of Moodle.

Numerous research studies have been conducted on Moodle's usability evaluation, with very less focus on the navigational evaluation of Moodle. Therefore, exploring the effectiveness of the navigational aspects of Moodle in the context of usability becomes appealing. Moreover, guidelines for the development of navigational structure of the LMS is also missing.

\section{RESEARCH DESIGN}

We first propose a navigational evaluation framework for LMS. After that a survey is conducted in order to get the feedback on the evaluation framework from users of Moodle. For this purpose both quantitative and qualitative research methods were used.

Our research is twofold in which two different types of questionnaires, first generic questionnaire and second tasks specific questionnaire, were constructed. Generic questionnaire was comprising questions based on factors of proposed evaluation framework, whereas task based questionnaire contained of questions regarding navigation of the most frequently performed tasks by both teachers and students.

Participants of this study were selected from the two leading universities of Pakistan. Participants were divided into two different groups: students and teachers. In case of selecting sample of students, we conducted our survey on Bachelor's level students' from both universities in which IT students were selected. Reason for selecting the IT students was that they had similar knowledge of using computer.

\section{NAVIGATIONAL EVALUATION FRAMEWORK FOR LMS}

In the context of LMS, the navigation has a significant impact on learning and teaching activities. Thus, it is important that the LMS should have an efficient navigation structure. In addition, there should be a framework against which usability experts and system analysts can evaluate the navigational structure of LMS.

Fig. 1 shows the proposed framework, underlining the most important aspects to be considered for evaluating the navigation structure of the LMS. The framework consists of seven major navigation factors and each major factor further comprises sub factors. The major factors of the framework are links, navigation menu, shortcut facility, services, navigation aids, consistency, and adaptive navigation.

Links category defines the main tool of hypertext design where various nodes (web pages, documents and multimedia) are linked together through hyperlinks. It provides the fundamental navigation mechanism to move around the web site and access various functionalities and perform tasks. Links can be text-based, navigational buttons or in the form of icons/images.

Menus are helpful to categorize the hyperlinks for easy navigation. Placement of these menus is significant in the usability of any Web application. Menu position can be vertical or horizontal. Moreover, menu structure in terms of its depth and breadth affects the user's ability to reach a particular page using the menus.

Shortcuts increase the work performance of users by making them able to quickly access the information that they needed. There are many ways to provide shortcuts such as; history list, key shortcuts, and bookmarks.

Services aspect considers three sub-aspects: customizability, search function, and help services. These aspects refer to the support that assist and help the users during the navigation through e-learning system.

Navigation aids provide users helpful information and support during the navigation. Navigational structure, breadcrumbs, sitemaps and frames are few of the aids that provide constant feedback to users about where they are, and where they can go next in a particular web application.

Consistency is one of the important usability factors in any design endeavor and is equally important to enhance navigation speed in the context of LMS. Therefore, we take it as a separate aspect in our framework for good navigation structure. Inconsistency slows down the users to perform their tasks and find the relevant information. When users move through pages in any LMS, they should be provided with similar information, placement of menus/hyperlinks and accessibility of options in a similar way on every page. If consistency is kept in different modules in displaying the information it reduces navigation effort as users do not require wondering about how to move around.

The adaptive navigation support (ANS) is a set of techniques used to assist individual users to locate an appropriate navigation path to the goals and preferences in the context of hypermedia and hypertext, by adapting link presentation. ANS helps to overcome the limitations of static links presentations that provide the same set of links and page contents to all users, although users are relatively diverse by needs and preferences. Adaptive hiding and adaptive sorting are two sub factors in this category.

The primary goal of the proposed framework is to examine the efficiency of the navigation structure of any LMSs. By doing this, several navigational problems can be highlighted and improvements can be made to improve the navigation structure. This in turn leads to a better user experience and supportive learning environment. 


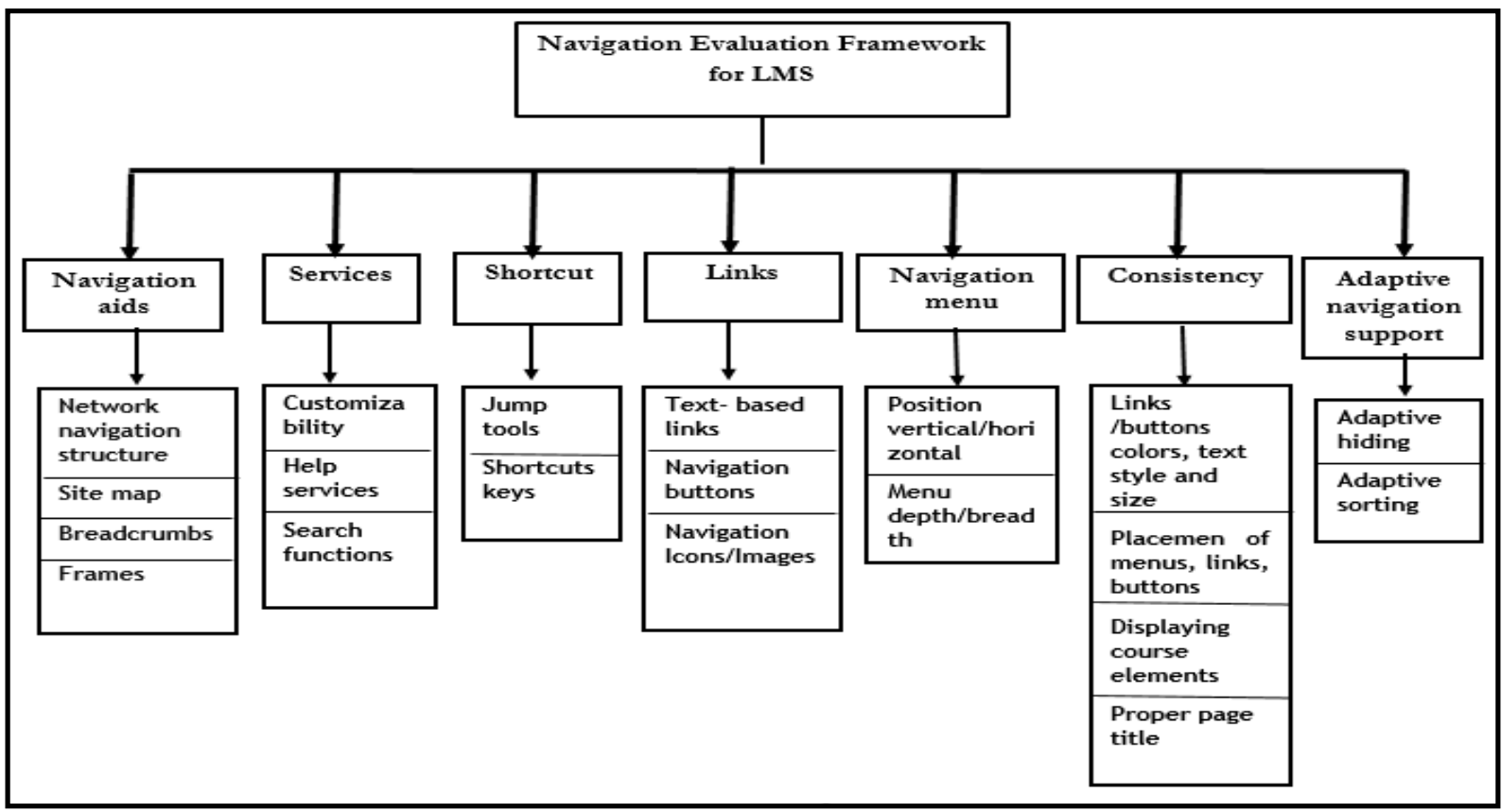

Fig. 1. Evaluation Framework

\section{RESULTS AND ANALYSIS}

Data collected through surveys is analysed using simple comparisons as well as advanced statistical techniques like Pearson correlation. This data was collected from two universities of Pakistan. For confidentiality reasons, these universities are referred as U1 and U2.

\section{A. Analysis of generic questionnaire}

The purpose of generic questionnaire was to get the opinion of students and teachers on the navigation structure of Moodle. Summary of the number of respondents on a generic questionnaire from both universities is presented in TABLE I.

Figure 2 shows a summary of usage of Moodle by students. It can be seen that most students of both universities use Moodle several times a week. Figure 3 indicates that most teachers of U1 used Moodle several times a week while at U2

TABLE I. NUMBER OF PARTICIPANTS IN GENERIC QUESTIONNAIRE

\begin{tabular}{|l|l|l|l|l|l|l|}
\hline \multirow{2}{*}{} & \multicolumn{2}{|c|}{ U1 } & \multicolumn{2}{c|}{ U2 } \\
\cline { 2 - 7 } & Male & Female & TOTAL & Male & Female & TOTAL \\
\hline Students & 47 & 25 & 72 & 44 & 24 & 68 \\
\hline Teachers & 2 & 2 & 4 & 4 & 2 & 6 \\
\hline Collective responses of Students $=140$ \\
Collective responses of Teachers $=10$
\end{tabular}

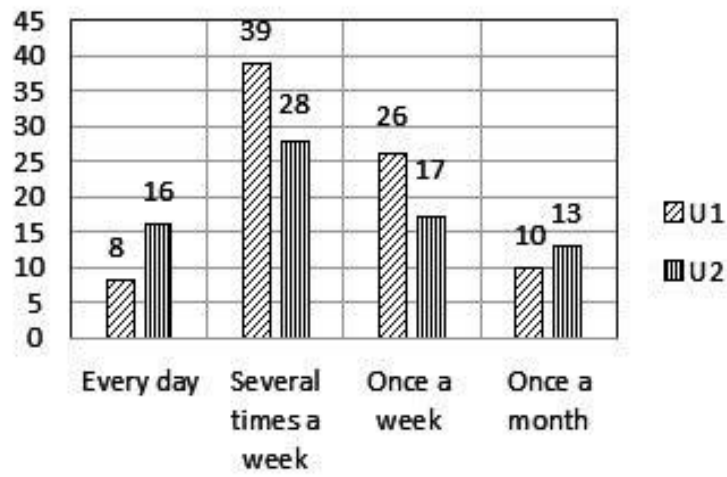

Fig. 2. Moodle usage by students

\section{1) Links}

TABLE II shows results of questions asked under the aspect links. Responses from both universities show that home link is available on every page of Moodle; no back to top link; icons and links/button text presented desired meaning to many of the respondents; no highlighted techniques are used; visited and unvisited links are not distinguishable.

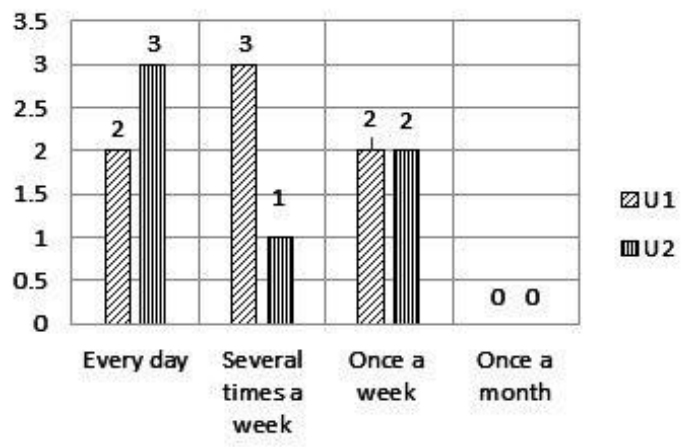

Fig. 3. Moodle usage by teachers

\section{U1 \\ 四2

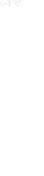


TABLE II. LINKS EVALUATION

\begin{tabular}{|c|c|c|c|c|}
\hline \multirow{2}{*}{\multicolumn{2}{|c|}{ Links }} & \multicolumn{2}{|r|}{ U2 } & \multirow{2}{*}{\begin{tabular}{|l|} 
TOTAL \\
SA A N D SD
\end{tabular}} \\
\hline & & $\begin{array}{lllll}\text { SA } & A & \text { N } & \text { D SD }\end{array}$ & SA A N D SD & \\
\hline \multirow{2}{*}{\multicolumn{2}{|c|}{ Home Link }} & $\begin{array}{lllll}16 & 60 & 2 & 3 & 2\end{array}$ & $\begin{array}{lllll}20 & 50 & 3 & 1 & 0\end{array}$ & \multirow{2}{*}{$\begin{array}{lllll}41 & 117 & 6 & 5 & 2\end{array}$} \\
\hline & & \begin{tabular}{|lllll}
2 & 4 & 0 & 1 & 0
\end{tabular} & $\begin{array}{lllll}3 & 3 & 1 & 0 & 0\end{array}$ & \\
\hline \multirow{2}{*}{\multicolumn{2}{|c|}{ Back t }} & $\begin{array}{lllll}10 & 15 & 3 & 40 & 16\end{array}$ & $\begin{array}{lllll}15 & 13 & 6 & 18 & 22\end{array}$ & \multirow{2}{*}{$26 \begin{array}{lllll}26 & 29 & 10 & 64 & 41\end{array}$} \\
\hline & & $\begin{array}{lll}1 & 3 & 2\end{array}$ & $\begin{array}{|lllll|}1 & 0 & 0 & 3 & 1\end{array}$ & \\
\hline \multirow{2}{*}{\multicolumn{2}{|c|}{$\begin{array}{l}\text { Icons and } \\
\text { links/buttons text } \\
\text { relevance }\end{array}$}} & \begin{tabular}{lllll|}
17 & 58 & 8 & 2 & 0 \\
\end{tabular} & $\begin{array}{llllll}19 & 44 & 10 & 1 & 0 \\
\end{array}$ & \multirow[b]{2}{*}{$\begin{array}{lllll}36 & 107 & 23 & 6 & 0\end{array}$} \\
\hline & & $\begin{array}{llll}0 & 0 & 4 & 3\end{array}$ & $\begin{array}{lllll}0 & 5 & 1 & 0 & 0\end{array}$ & \\
\hline \multirow{2}{*}{$\begin{array}{l}\text { Use of highlighting } \\
\text { techniques }\end{array}$} & & $\begin{array}{lllll}6 & 30 & 36 & 9 & 2\end{array}$ & $\begin{array}{lllll}12 & 21 & 27 & 12 & 2\end{array}$ & \multirow{2}{*}{$\begin{array}{lllll}19 & 58 & 66 & 22 & 5\end{array}$} \\
\hline & & $\begin{array}{llllll}0 & 3 & 3 & 1 & 0\end{array}$ & $\begin{array}{lllll}1 & 4 & 0 & 0 & 1\end{array}$ & \\
\hline \multirow{2}{*}{\multicolumn{2}{|c|}{$\begin{array}{l}\text { Distinguishable } \\
\text { visited and unvisited } \\
\text { links }\end{array}$}} & $\begin{array}{lllll}3 & 22 & 22 & 24 & 12\end{array}$ & $\begin{array}{llllll}8 & 14 & 14 & 31 & 7\end{array}$ & \multirow{2}{*}{$\begin{array}{lllll}11 & 39 & 38 & 62 & 20\end{array}$} \\
\hline & & $\begin{array}{lllll}0 & 1 & 1 & 4 & 1\end{array}$ & $\begin{array}{lllll}0 & 2 & 1 & 3 & 0\end{array}$ & \\
\hline
\end{tabular}

$\mathrm{SA}=$ strongly agree, $\mathrm{A}=$ agree, $\mathrm{N}=$ neutral, $\mathrm{D}=$ disagree, $\mathrm{SD}=$ strongly disagree $-\mathrm{S}=$ Students, $\mathrm{T}=$ Teachers

\section{2) Мепи}

TABLE III shows results of questions related to navigation menu. Results depict that most of the respondents found required items in navigation block and also the arrangement of items in the navigation block seemed to be logical, but still a few of them remained neutral that indicates menu items should be arranged in a more logical structure. Although many respondents reported that they were able to reach some particular destination with minimum clicks, but few of them reported that many steps are required to reach some sections.

TABLE III. Navigation Menu Evaluation

\begin{tabular}{|c|c|c|c|c|}
\hline \multirow{2}{*}{$\begin{array}{l}\text { Navigation } \\
\text { menu }\end{array}$} & & 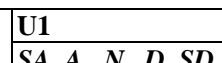 & U2 & \multirow{2}{*}{\begin{tabular}{|l|l} 
TOTAL \\
$S A A A N D S D$
\end{tabular}} \\
\hline & & $\begin{array}{lllll}S A & A & N & D & S D\end{array}$ & $S A A N A D$ & \\
\hline \multirow{2}{*}{$\begin{array}{l}\text { Availability } \\
\text { of required } \\
\text { option in } \\
\text { navigation } \\
\text { block }\end{array}$} & & $\begin{array}{lllll}12 & 40 & 27 & 2 & 2\end{array}$ & \begin{tabular}{lllll|}
12 & 29 & 24 & 8 & 1
\end{tabular} & \multirow[b]{2}{*}{$\begin{array}{lllll}26 & 75 & 54 & 12 & 3\end{array}$} \\
\hline & & $\begin{array}{lllll}1 & 3 & 2 & 1 & 0\end{array}$ & $\begin{array}{lllll}1 & 3 & 1 & 1 & 0\end{array}$ & \\
\hline \multirow{2}{*}{\begin{tabular}{|l|} 
Arrangements \\
of navigation \\
items is \\
logical \\
\end{tabular}} & & \begin{tabular}{|lllll}
5 & 52 & 17 & 7 & 2
\end{tabular} & $\begin{array}{lllll}12 & 35 & 19 & 6 & 2\end{array}$ & \multirow[b]{2}{*}{$\begin{array}{lllll}17 & 96 & 39 & 14 & 4\end{array}$} \\
\hline & $\mathrm{T}$ & $\begin{array}{lllll}0 & 3 & 3 & 1 & 0\end{array}$ & $\begin{array}{lll}0 & 6 & 0\end{array}$ & \\
\hline \multirow{2}{*}{$\begin{array}{l}\text { Appropriate } \\
\text { menu depth }\end{array}$} & $\mathrm{S}$ & $\begin{array}{|lllll|}4 & 47 & 21 & 5 & 6 \\
\end{array}$ & $\begin{array}{llllll}15 & 26 & 16 & 13 & 4 \\
\end{array}$ & \multirow[b]{2}{*}{$\begin{array}{lllll}19 & 81 & 42 & 18 & 10\end{array}$} \\
\hline & & $\begin{array}{|llll|}0 & 1 & 1 & 4\end{array}$ & $\begin{array}{|lllll|}0 & 2 & 1 & 3 & 0\end{array}$ & \\
\hline
\end{tabular}

$\mathrm{SA}=$ strongly agree, $\mathrm{A}=$ agree, $\mathrm{N}=$ neutral, $\mathrm{D}=$ disagree, $\mathrm{SD}=$ strongly disagree $-\mathrm{S}=$ Students, $\mathrm{T}=$ Teachers

\section{3) Navigational Aids}

TABLE IV shows results of questions asked under the aspect navigational aids. The responses received on subaspects under this category reveal that mostly respondents were free to move in a non-sequential path; sitemap is not available in Moodle; bread crumbs are available; different sections of the screen are divided into different blocks.
TABLE IV. NAVIGATIONAL Aids Evaluation

\begin{tabular}{|c|c|c|c|c|}
\hline \multirow{2}{*}{ Links } & & U1 & U2 & TOTAL \\
\hline & & \begin{tabular}{|lllll} 
SA A & N & D SD
\end{tabular} & SA A N D SD & SA A N D SD \\
\hline \multirow{2}{*}{$\begin{array}{l}\text { Network } \\
\text { navigation }\end{array}$} & & $\begin{array}{lllll}11 & 48 & 14 & 8 & 2\end{array}$ & $\begin{array}{lllll}12 & 33 & 18 & 10 & 1\end{array}$ & \multirow{2}{*}{$\begin{array}{lllll}24 & 85 & 38 & 20 & 3\end{array}$} \\
\hline & & $\begin{array}{lllll}0 & 3 & 4 & 0 & 0\end{array}$ & $\begin{array}{lllll}1 & 1 & 2 & 2 & 0\end{array}$ & \\
\hline \multirow{2}{*}{ Sitemap } & & $\begin{array}{lllll}3 & 15 & 18 & 40 & 7\end{array}$ & $15 \quad 8 \quad 6 \quad 23 \quad 22$ & \multirow{2}{*}{$\begin{array}{lllll}19 & 26 & 24 & 68 & 32\end{array}$} \\
\hline & & $\begin{array}{|lllll|}0 & 2 & 1 & 2 & 2\end{array}$ & $\begin{array}{|lllll|}1 & 1 & 0 & 3 & 1 \\
\end{array}$ & \\
\hline \multirow{2}{*}{ Breadcrumbs } & $\mathrm{S}$ & \begin{tabular}{lllll|}
17 & 33 & 12 & 11 & 10
\end{tabular} & $\begin{array}{lllll}11 & 25 & 26 & 10 & 2\end{array}$ & \multirow{2}{*}{ 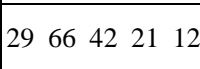 } \\
\hline & $\mathrm{T}$ & $\begin{array}{|lllll|} & 4 & 2 & 0 & 0\end{array}$ & \begin{tabular}{lllll|}
0 & 4 & 2 & 0 & 0
\end{tabular} & \\
\hline \multirow{2}{*}{ Frames } & S & $\begin{array}{lllll}6 & 40 & 21 & 8 & 8\end{array}$ & $\begin{array}{lllll}15 & 34 & 17 & 7 & 1\end{array}$ & \multirow{2}{*}{$\begin{array}{lllll}23 & 82 & 41 & 15 & 9\end{array}$} \\
\hline & $\mathrm{T}$ & $\begin{array}{|llll|}1 & 6 & 0 & 0 \\
\end{array}$ & $1 \quad 2$ & \\
\hline
\end{tabular}

$\mathrm{SA}=$ strongly agree, $\mathrm{A}=$ agree, $\mathrm{N}=$ neutral, $\mathrm{D}=$ disagree, $\mathrm{SD}=$ strongly disagree $-\mathrm{S}=$ Students, $\mathrm{T}=$ Teachers

4) Shortcuts facility

TABLE $\mathrm{V}$ shows results of questions asked under the aspect shortcuts facility. Results indicate that most students agreed that they are provided with the facility of the history list and bookmarks. However, most respondents remained neutral that shortcut keys are available in order to access different materials in Moodle.

TABLE V. SHORTCUTS FACILITY EVALUATION

\begin{tabular}{|c|c|c|c|c|}
\hline \multirow{2}{*}{ Links } & & U1 & $\mathbf{U 2}$ & \multirow{2}{*}{\begin{tabular}{|l|} 
TOTAL \\
SA A N D SD \\
\end{tabular}} \\
\hline & & \begin{tabular}{|lllll} 
SA & A & N & D SD
\end{tabular} & $\begin{array}{llll}\text { SA } & A & \text { N } & \text { DD }\end{array}$ & \\
\hline \multirow{2}{*}{$\begin{array}{l}\text { Provision of } \\
\text { history list }\end{array}$} & $\mathrm{S}$ & $\begin{array}{lllll}11 & 39 & 21 & 6 & 6\end{array}$ & $\begin{array}{llll}16 & 28 & 16 & 122\end{array}$ & \multirow{2}{*}{$\begin{array}{lllll}29 & 71 & 42 & 20 & 8\end{array}$} \\
\hline & $\mathrm{T}$ & $\begin{array}{lllll}1 & 2 & 3 & 1 & 0\end{array}$ & $\begin{array}{lll}1 & 2 & 2\end{array}$ & \\
\hline \multirow{2}{*}{$\begin{array}{l}\text { Facility of } \\
\text { bookmarks }\end{array}$} & $\mathrm{S}$ & $\begin{array}{|lllll|}11 & 28 & 20 & 15 & 9\end{array}$ & $\begin{array}{lllll}14 & 24 & 16 & 18 & 2\end{array}$ & \multirow{2}{*}{$265841 \quad 34 \quad 11$} \\
\hline & $\mathrm{T}$ & $\begin{array}{|lllll|}0 & 3 & 4 & 0 & 0\end{array}$ & $\begin{array}{lll}1 & 3 & 1\end{array}$ & \\
\hline \multirow{2}{*}{$\begin{array}{l}\text { Shortcut keys } \\
\text { facility }\end{array}$} & $S$ & $\begin{array}{|lllll|}2 & 13 & 22 & 27 & 19 \\
\end{array}$ & $\begin{array}{|lllll|}4 & 16 & 24 & 25 & 5 \\
\end{array}$ & \multirow{2}{*}{733505624} \\
\hline & $\mathrm{T}$ & \begin{tabular}{|lll}
0 & 1 & 1
\end{tabular} & 2 & \\
\hline
\end{tabular}

$\mathrm{SA}=$ strongly agree, $\mathrm{A}=$ agree, $\mathrm{N}=$ neutral, $\mathrm{D}=$ disagree, $\mathrm{SD}=$ strongly disagree $-\mathrm{S}=$ Students, $\mathrm{T}=$ Teachers

\section{5) Services}

TABLE VI shows results of questions asked under the aspect shortcuts facility. Results indicate that most students remained neutral that they were able to customize page layout and courses according to their need and preference, while teachers agreed that they are provided with the service of customizability. Equal number of teachers agreed and remained neutral that help services give concise and easy-tounderstand instructions.

Apart from teachers' responses, mostly students remained neutral that help services provide concise and easy to understand help instruction and also reported that there should be a direct help button. Most of the respondents strongly disagreed that they were able to find information, course, assignment, and lecture files, etc. through a search function, it means no powerful search function is available in Moodle. 
TABLE VI. SERVICES EVALUATION

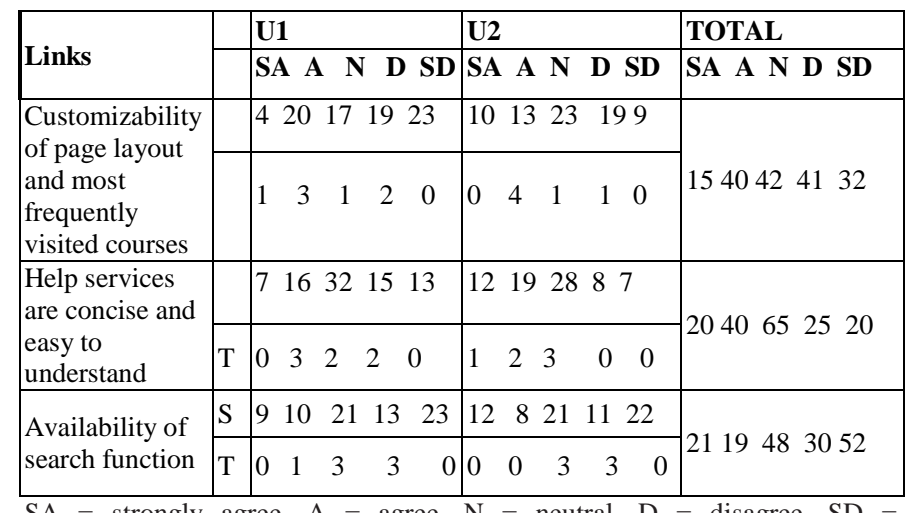

$\mathrm{SA}=$ strongly agree, $\mathrm{A}=$ agree, $\mathrm{N}=$ neutral, $\mathrm{D}=$ disagree, $\mathrm{SD}=$ strongly disagree $-\mathrm{S}=$ Students, $\mathrm{T}=$ Teachers

6) Adaptive Navigation Support (ANS)

Pertaining to adaptive navigation, result (TABLE VII) depicts that most of the respondents disagreed that Moodle has support for adaptive navigation (adaptive sorting and adaptive hiding).

TABLE VII. ADAPTIVE NAVIGATION EVALUATION

\begin{tabular}{|c|c|c|c|c|}
\hline \multirow[b]{2}{*}{ Links } & & $\mathrm{U1}$ & $\mathrm{U} 2$ & \multirow{2}{*}{\begin{tabular}{|l|} 
TOTAL \\
SA A N D SD \\
\end{tabular}} \\
\hline & & \begin{tabular}{|lllll} 
SA & A & N & D & SD
\end{tabular} & $\begin{array}{lllll}\text { SA } & \text { A } & \text { N } & \text { D } & \text { SD }\end{array}$ & \\
\hline \multirow{2}{*}{$\begin{array}{l}\text { Adaptive } \\
\text { hiding }\end{array}$} & & $\begin{array}{llllll}2 & 15 & 15 & 21 & 30\end{array}$ & \begin{tabular}{|llllll}
9 & 5 & 10 & 24 & 26
\end{tabular} & \multirow{2}{*}{1226274956} \\
\hline & & $\begin{array}{|lllll|}1 & 2 & 1 & 3 & 0\end{array}$ & $\begin{array}{|lll|}0 & 4 & 1 \\
\end{array}$ & \\
\hline \multirow{2}{*}{$\begin{array}{l}\text { Adaptive } \\
\text { sorting }\end{array}$} & & $\begin{array}{|lllll|}5 & 10 & 13 & 30 & 25\end{array}$ & $\begin{array}{|lllll|}2 & 12 & 17 & 23 & 20\end{array}$ & \multirow{2}{*}{$8263457 \quad 45$} \\
\hline & $\mathrm{T}$ & $\begin{array}{|lllll|}0 & 2 & 2 & 3 & 0\end{array}$ & $\begin{array}{|lllll|}1 & 2 & 2 & 1 & 0\end{array}$ & \\
\hline
\end{tabular}

$\mathrm{SA}=$ strongly agree, $\mathrm{A}=$ agree, $\mathrm{N}=$ neutral, $\mathrm{D}=$ disagree, $\mathrm{SD}=$ strongly disagree $-\mathrm{S}=$ Students, $\mathrm{T}=$ Teacher

7) Consistency

Results (TABLE VIII) under this aspect show that most respondents agreed that Moodle maintains consistency in links/buttons colors, text style and size. Some respondents remained neutral and that shows they did not find consistency in these elements throughout the use of Moodle. Again, most of the respondents found consistency in placement of menus, buttons and, links, but significant number of users remained neutral that shows they did not find consistency in placement of these navigation items. The result also depicts that most respondents agreed that there is consistency in displaying the course elements for different courses and every page of Moodle is properly titled. Despite this, some of the respondents reported that page title is not fixed in its location and moves up when the page is scrolled down.
TABLE VIII. CONSISTENCY Evaluation

\begin{tabular}{|c|c|c|c|c|}
\hline \multirow[b]{2}{*}{ Links } & & U1 & U2 & \multirow{2}{*}{\begin{tabular}{|l|} 
TOTAL \\
SA A N D SD
\end{tabular}} \\
\hline & & $\begin{array}{lllll}\text { SA } & A & N & \text { D } & \text { SD }\end{array}$ & SA A N D SD & \\
\hline \multirow{2}{*}{$\begin{array}{l}\text { Consistency in } \\
\text { colors, size, } \\
\text { text style of } \\
\text { navigation } \\
\text { items }\end{array}$} & & $\begin{array}{|lllll|}8 & 41 & 23 & 5 & 6\end{array}$ & $12 \quad 3122 \quad 63$ & \multirow[b]{2}{*}{$\begin{array}{lllll}24 & 79 & 47 & 11 & 9\end{array}$} \\
\hline & & $\begin{array}{lllll}1 & 5 & 1 & 0 & 0\end{array}$ & $\begin{array}{lllll}3 & 2 & 1 & 0 & 0\end{array}$ & \\
\hline \multirow{2}{*}{$\begin{array}{l}\text { Placement of } \\
\text { navigation } \\
\text { items is } \\
\text { standard } \\
\end{array}$} & & $\begin{array}{lllll}12 & 26 & 37 & 4 & 4\end{array}$ & $\begin{array}{lllll}11 & 40 & 20 & 3 & 0\end{array}$ & \multirow[t]{2}{*}{$\begin{array}{lllll}23 & 74 & 59 & 10 & 4\end{array}$} \\
\hline & & $\begin{array}{|lllll|}0 & 4 & 1 & 2 & 0\end{array}$ & $\begin{array}{|lllll|}0 & 4 & 1 & 1 & 0\end{array}$ & \\
\hline \multirow{2}{*}{$\begin{array}{l}\text { Placement of } \\
\text { courses is } \\
\text { consistent }\end{array}$} & $S$ & $\begin{array}{lllll}1 & 46 & 18 & 4 & 4 \\
\end{array}$ & $1437 \quad 20 \quad 12$ & \multirow{2}{*}{$\begin{array}{lllll}26 & 91 & 41 & 6 & 6\end{array}$} \\
\hline & $\mathrm{T}$ & $\begin{array}{lllll}0 & 5 & 1 & 1 & 0\end{array}$ & $\begin{array}{lllll}1 & 3 & 2 & 0 & 0\end{array}$ & \\
\hline \multirow{2}{*}{$\begin{array}{l}\text { Every page is } \\
\text { titled } \\
\text { properly }\end{array}$} & $S$ & $\begin{array}{lllll}13 & 50 & 17 & 1 & 2 \\
\end{array}$ & $\begin{array}{lllll}17 & 34 & 17 & 4 & 2 \\
\end{array}$ & \multirow[b]{2}{*}{$\begin{array}{lllll}35 & 89 & 37 & 5 & 4\end{array}$} \\
\hline & 1 & $\begin{array}{llll}3 & 2 & 2 & 0\end{array}$ & $\begin{array}{lllll}2 & 3 & 1 & 0 & 0\end{array}$ & \\
\hline
\end{tabular}

$\mathrm{SA}=$ strongly agree, $\mathrm{A}=$ agree, $\mathrm{N}=$ neutral, $\mathrm{D}=$ disagree, $\mathrm{SD}=$ strongly disagree $-\mathrm{S}=$ Students, $\mathrm{T}=$ Teachers

\section{8) Overall experience of navigation}

Pertaining to the overall experience of navigation in Moodle we asked three questions in which respondents were required to rate their experience of ease of navigation, satisfaction about navigation design, and whether navigation design of Moodle helped accomplish tasks efficiently. Responses received against each question, depict that most respondents agreed that they experienced ease of navigation in Moodle easy. Results also show that most of the respondents were satisfied about navigation design of Moodle and agreed that navigation structure of Moodle helped them perform tasks efficiently (TABLE IX).

TABLE IX. OVERALL EXPERIENCE OF NAVIGATION

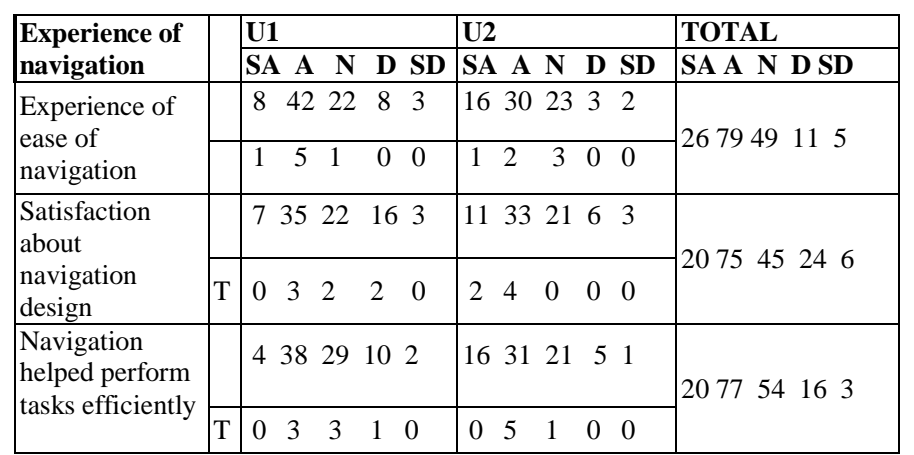

$\mathrm{SA}=$ strongly agree, $\mathrm{A}=$ agree, $\mathrm{N}=$ neutral, $\mathrm{D}=$ disagree, $\mathrm{SD}=$ strongly disagree $-\mathrm{S}=$ Students, $\mathrm{T}=$ Teachers 


\section{B. Responses on subjective questions}

Subjective questions were also very important in order to assess the Moodle navigation structure in accordance with the student's and teacher's perspectives. This allowed the users to write any problems they faced and to provide suggestions for making the improvement in navigation design of Moodle.

First subjective question in our survey was "Describe any problems you encountered in navigation design of Moodle". Users identified 30 problems and after closer review and classification, we found the following seven unique problems:

1) There is no back to top page button.

2) Sometimes users face difficulty in finding required content.

3) Navigation block has a lot of contents and font size is very small.

4) The information that has been displayed in a particular manner is confusing and increases stress on the mind.

5) Navigation is quite deep and sometimes requires a lot of steps to reach the required information/page.

6) Some links which are not relevant to users are still visible to them.

7) There is no direct Help button available.

The second subjective question in our survey was "Do you have any suggestions to improve the navigation structure of Moodle?" Some distinct answers from respondents were:

1) It should add video tutorials help for making easy for the students to use. For novice users' it is quite difficult.

2) Links should be disable and enable according to the users' requirements.

3) Links should be more structured and meaningful.

4) Icons should be more readable.

5) Include a helpful site map.

6) Navigational structure should highlight the important navigations.

7) A fixed menu on the left side would look and feel better.

8) Minimize the text and links in the navigation block.

9) Layout should change, it should add help feature.

10)Steps should be decreased for various sections.

11)Navigation structure should be improved by providing access to all pages from HOME menu, and buttons should be provided according to recently used history.

\section{Analysis of task based questionnaire}

In order to examine navigation of most frequently performed tasks in Moodle, this questionnaire was prepared. Each task had some set of questions, including not only the task to be performed, but also some questions regarding efficient navigation. The objective of this questionnaire was to get the users' feedback on how they experienced Moodle in performing each task and also to reveal which tasks the participants were experiencing as easy or difficult. For students, we used lab-based usability testing method in which they were being observed while performing each task. Proper help was provided to students in case of any problem. Whereas, for teachers, we sent a questionnaire through e-mail to them so they could fill it up on their workplace. Summary of the number of respondents from both universities is presented in TABLE $\mathrm{X}$.

\section{1) Students'perspectives - Usability test}

Students were required to perform following four tasks; upload and submit an assignment, access a lecture, access the weekly plan, and attempt a quiz in Moodle. The student sample included students from first year to fourth year, varying their level of experience with using the selected LMS. Figure 4 depicts the number of students participated in this usability test according to year of studies at both universities.

TABLE X. Number of PARTICIPANTS ON TASK- BASED QUESTIONNAIRE

\begin{tabular}{|l|l|l|l|l|l|l|}
\hline \multirow{2}{*}{} & \multicolumn{3}{|c|}{ U1 } & \multicolumn{3}{c|}{ U2 } \\
\cline { 2 - 7 } & Male & Female & TOTAL & Male & Female & TOTAL \\
\hline Students & 47 & 25 & 72 & 44 & 24 & 68 \\
\hline Teachers & 2 & 2 & 4 & 4 & 2 & 6 \\
\hline \multicolumn{6}{|l|}{ Collective responses of Students $=140$} \\
Collective responses of Teachers $=10$
\end{tabular}

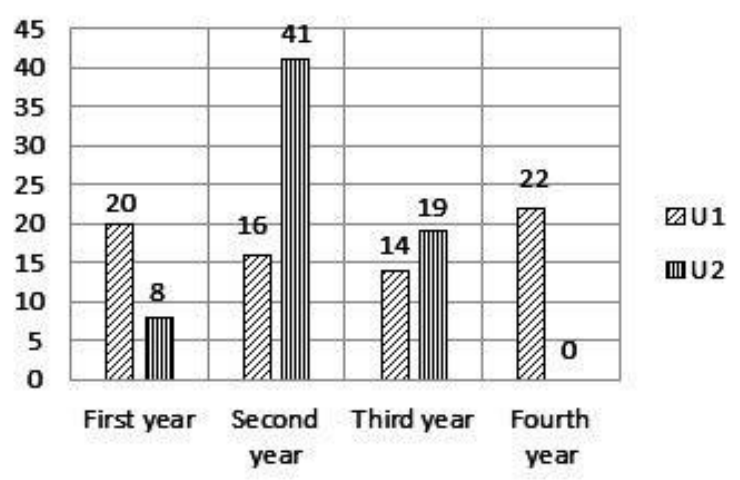

Fig. 4. Students' educational experience (in terms of degree year)

Figure 5 represents the experience of students with the use of Moodle. This figure shows that most students of both universities were experienced with Moodle and results of overall response shows that most students had experience with the use of Moodle.

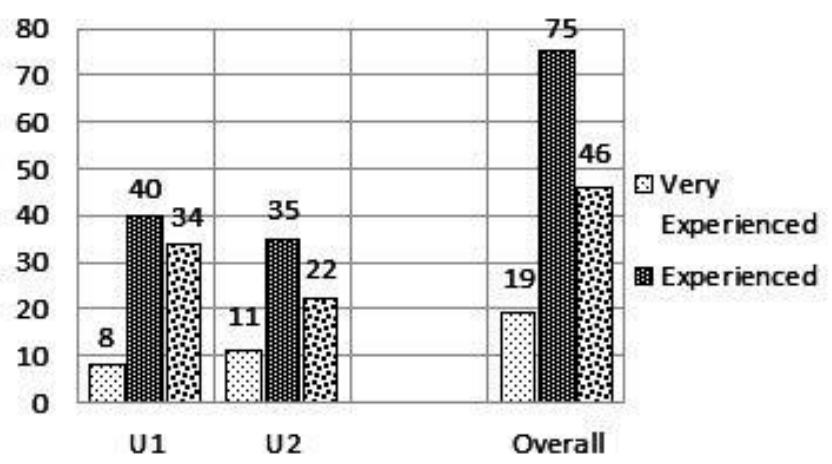

Fig. 5. Experience of students in using Moodle

a) Task-one: Upload and submit an assignment

Result: For Q1, the majority of students at both universities agreed that they could attach and submit an 
assignment with minimum clicks. In Q2, the majority of students reported that button "Save Changes" presented desired meaning to them. But still some students reported that button text should be more meaningful as "Submit" or "Send". For Q3, again majority of students from both universities agreed that submitted assignment status is shown in "RECENT ACTIVITY" block that reduces clicking effort, as they do not require to click particular assignment to check its status that whether it has been submitted for grading or not yet. For Q4, most students at both universities agreed that button/link text presented desired meaning to them (TABLE XI).

TABLE XI. RESPONSES ON TASK ONE

\begin{tabular}{|c|c|c|c|}
\hline \multirow[b]{2}{*}{ Q\# } & U1 & U2 & TOTAL \\
\hline & SA A $N$ D SD & $\begin{array}{lllll}\text { SA } & \text { A } & N & \text { D } & \text { SD }\end{array}$ & SA A N D SD \\
\hline Q1 & $\begin{array}{lllll}12 & 47 & 8 & 4 & 1\end{array}$ & $\begin{array}{lllll}7 & 31 & 13 & 10 & 1\end{array}$ & $\begin{array}{lllll}19 & 82 & 21 & 14 & 2\end{array}$ \\
\hline Q2 & $\begin{array}{lllll}22 & 36 & 4 & 9 & 1\end{array}$ & $\begin{array}{lllll}15 & 37 & 11 & 2 & 3\end{array}$ & $\begin{array}{lllll}37 & 73 & 15 & 11 & 4\end{array}$ \\
\hline Q3 & $\begin{array}{lllll}9 & 37 & 15 & 5 & 6\end{array}$ & $\begin{array}{lllll}7 & 31 & 18 & 7 & 5\end{array}$ & $\begin{array}{lllll}16 & 68 & 27 & 18 & 11\end{array}$ \\
\hline Q4 & $\begin{array}{lllll}5 & 45 & 13 & 8 & 1\end{array}$ & $\begin{array}{lllll}8 & 29 & 18 & 11 & 2\end{array}$ & $\begin{array}{lllll}13 & 74 & 31 & 19 & 3\end{array}$ \\
\hline
\end{tabular}

b) Task-two: Download a Lecture

Results: For Q1 students at both universities reported that they were able to easily access recently uploaded lectures. Pertaining to Q2 majority of students from both universities agreed that files are easily downloaded. However, some students reported that sometime download links do not work properly. In Q3, we asked the students whether they mostly use "RECENT ACTIVITY" block to access uploaded lecture files and responses from students show that students at U1 were preferred this block while students at U2 disagreed with this, showing under course page they used to download lecture files. Lastly, for Q4, the majority of the students from both universities reported that minimum clicks were required to download the lecture files (TABLE XII).

TABLE XII. RESPONSES ON TASK TWO

\begin{tabular}{|c|l|lllll|lllllll|lllll|}
\hline \multirow{2}{*}{ Q\# } & U1 & U & SA & A & N & D & SD & SA & A & N & D & SD & SA & A & N & D & SD \\
\hline Q1 & 18 & 40 & 9 & 4 & 1 & 13 & 39 & 9 & 5 & 2 & 31 & 79 & 18 & 9 & 3 \\
\hline Q2 & 20 & 39 & 11 & 1 & 1 & 21 & 29 & 12 & 3 & 3 & 41 & 68 & 23 & 4 & 4 \\
\hline Q3 & 7 & 23 & 20 & 13 & 9 & 9 & 16 & 10 & 22 & 11 & 16 & 39 & 30 & 35 & 20 \\
\hline Q4 & 17 & 42 & 12 & 1 & 0 & 21 & 30 & 7 & 7 & 3 & 38 & 72 & 19 & 8 & 3 \\
\hline
\end{tabular}

$\mathrm{SA}=$ strongly agree, $\mathrm{A}=$ agree, $\mathrm{N}=$ neutral, $\mathrm{D}=$ disagree, $\mathrm{SD}=$ strongly disagree

c) Task-three: View/Access weekly plan

Result: Pertaining to Q1, in which we asked whether they get notified when a new lecture, assignment or quiz is uploaded on Moodle, students of U1 remained neutral while students of U2 disagreed, the reason for these responses could be that students at U1 considered that upcoming events for particular course are shown in "Upcoming Events" block- a source to get users notified. Whereas, at U2, students disagreed because there was no such facility available from where students can check the upcoming events for their all enrolled courses from a single page. Also, some of the students argued that to check upcoming events such as assignment, quizzes, and uploaded lectures they are required to check each course page separately- requiring many clicks. There should be a separate page that maintains a list of upcoming assignments, lectures, and quizzes for all subjects. Further, the result of this task indicates that majority of students agreed in Q2-Q3, and Q4 from both universities. This shows that students were required to perform minimum clicks to access the weekly plan, each week item is easily accessible under its respective course, and the current week is highlighted. In Q5 students at U1 agreed as they reported that in "Upcoming Events" block upcoming assignments and quizzes are shown with due dates and students at U2 were remained neutral in their responses but did not provide any supporting statements. Pertaining to Q6 most of the students disagreed from both universities indicated that weekly items, assignments and quizzes are not highlighted when submission date is near. Students stated that links should be highlighted when announcement for new lectures, assignment or quizzes is made; and when submission date is near for submitting the assignment and attempting the quiz. For Q7 students at U1 disagreed and students at U2 strongly disagreed that weeks' dates with their items are able to expand and collapse (TABLE XIII).

TABLE XIII. RESPONSES ON TASK THREE

\begin{tabular}{|c|c|c|c|}
\hline \multirow[b]{2}{*}{ Q\# } & U1 & $\mathbf{U} 2$ & TOTAL \\
\hline & \begin{tabular}{lllll|} 
SA & $A$ & $N$ & D & SD
\end{tabular} & $\begin{array}{lllll}\text { SA } & \text { A } & \text { N } & \text { D } & \text { SD }\end{array}$ & 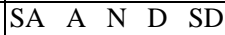 \\
\hline Q1 & $\begin{array}{|lllll|}9 & 8 & 34 & 11 & 10\end{array}$ & $\begin{array}{|lllll|}17 & 8 & 11 & 27 & 5\end{array}$ & $\begin{array}{lllll}26 & 16 & 45 & 38 & 15\end{array}$ \\
\hline Q2 & $\begin{array}{|lllll|}16 & 40 & 11 & 3 & 2\end{array}$ & $\begin{array}{|lllll|}9 & 34 & 12 & 9 & 4\end{array}$ & $\begin{array}{|lllll|}25 & 74 & 23 & 12 & 6\end{array}$ \\
\hline Q3 & $\begin{array}{|llll|}18 & 39 & 12 & 2\end{array}$ & \begin{tabular}{|lllll}
20 & 31 & 11 & 5 & 1
\end{tabular} & \begin{tabular}{lllll|}
38 & 70 & 23 & 7 & 2
\end{tabular} \\
\hline $\mathrm{Q} 4$ & $\begin{array}{|lllll|}10 & 32 & 16 & 8 & 6\end{array}$ & $\begin{array}{|lllll|}18 & 27 & 11 & 10 & 2 \\
\end{array}$ & $\begin{array}{|lllll|}28 & 59 & 27 & 18 & 8 \\
\end{array}$ \\
\hline Q5 & $\begin{array}{|lllll|}5 & 38 & 13 & 9 & 7\end{array}$ & \begin{tabular}{|lllll}
5 & 11 & 28 & 9 & 15
\end{tabular} & \begin{tabular}{lllll|}
10 & 49 & 41 & 18 & 22
\end{tabular} \\
\hline Q6 & $\begin{array}{|lllll|}3 & 14 & 21 & 29 & 5\end{array}$ & $\begin{array}{|lllll|}9 & 17 & 12 & 26 & 4\end{array}$ & $\begin{array}{|lllll|}12 & 31 & 33 & 55 & 9\end{array}$ \\
\hline Q7 & $\begin{array}{|lllll|}1 & 3 & 19 & 33 & 6\end{array}$ & $\begin{array}{|lllll|}10 & 13 & 4 & 18 & 23\end{array}$ & $\begin{array}{|lllll|}11 & 16 & 23 & 51 & 39\end{array}$ \\
\hline
\end{tabular}

\section{d) Task-four: Attempt a quiz}

Result: For Q1 students at both universities reported that they were able to easily access the quiz to be attempted. Pertaining to Q2 and Q3 majority of students from both universities agreed that they were able to navigate through different questions of the quiz. For Q4, the majority of students from both universities reported that they were able to finish their quiz on any question. For Q5 again majority of students from both universities reported that location of buttons/links in this module is easily noticeable. For Q6 at U1 most students agreed that button/link text presented desired meaning to them. While at $\mathrm{U} 2$, in response to this question majority of students remained neutral (TABLE XIV).

TABLE XIV. RESPONSES ON TASK FouR

\begin{tabular}{|c|lllll|lllllll|lllll|}
\hline \multirow{2}{*}{ Q\# } & U1 & & SA & A & N & D & SD & SA & A & N & D & SD & SA & A & N & D & SD \\
\hline & Q1 & 20 & 36 & 12 & 1 & 3 & 16 & 31 & 13 & 6 & 2 & 36 & 67 & 25 & 7 & 5 \\
\hline
\end{tabular}




\begin{tabular}{|l|lllll|lllll|lllll|}
\hline Q2 & 13 & 32 & 11 & 9 & 7 & 16 & 27 & 14 & 8 & 3 & 29 & 59 & 25 & 17 & 10 \\
\hline Q3 & 9 & 31 & 18 & 8 & 6 & 14 & 24 & 22 & 6 & 2 & 23 & 55 & 40 & 14 & 8 \\
\hline Q4 & 10 & 38 & 10 & 9 & 5 & 13 & 24 & 18 & 10 & 3 & 23 & 62 & 28 & 19 & 8 \\
\hline Q5 & 16 & 38 & 6 & 10 & 2 & 11 & 28 & 17 & 8 & 4 & 27 & 66 & 23 & 18 & 6 \\
\hline Q6 & 6 & 26 & 17 & 19 & 4 & 7 & 19 & 23 & 14 & 5 & 13 & 45 & 40 & 33 & 9 \\
\hline
\end{tabular}

$\mathrm{SA}=$ strongly agree, $\mathrm{A}=$ agree, $\mathrm{N}=$ neutral, $\mathrm{D}=$ disagree, $\mathrm{SD}=$ strongly disagree

After accomplishing all the tasks students were asked to rate the level of difficulty in accomplishing each task, and results indicate that most of the students of both universities found easy to perform all tasks in Moodle (TABLE XV).

TABLE XV. LEVEl OF Difficulty in PERforming EACH TASK

\begin{tabular}{|c|lllll|lllll|llllll|}
\hline \multirow{2}{*}{ Q\# } & U1 & UE & E & N & D & VD & VE & E & N & D & VD & VE & E & N & D & VD \\
\hline Q1 & 12 & 42 & 16 & 2 & 0 & 10 & 33 & 21 & 1 & 3 & 22 & 75 & 37 & 3 & 3 \\
\hline Q2 & 21 & 35 & 15 & 1 & 0 & 17 & 29 & 15 & 4 & 3 & 38 & 64 & 30 & 5 & 3 \\
\hline Q3 & 14 & 31 & 18 & 7 & 2 & 13 & 30 & 16 & 6 & 3 & 27 & 61 & 34 & 13 & 5 \\
\hline Q4 & 17 & 34 & 20 & 1 & 0 & 15 & 30 & 19 & 3 & 1 & 32 & 64 & 39 & 4 & 1 \\
\hline
\end{tabular}

$\mathrm{VE}=$ very easy, $\mathrm{E}=$ easy, $\mathrm{N}=$ neutral, $\mathrm{D}=$ difficult, $\mathrm{VD}=$ very difficult

Observed problem: The problem observed was that mostly first year students who had no prior or little experience of using Moodle, did not able to know how to attach an assignment for assessment and there was no proper help available in Moodle. The majority of the students struggled with understanding the Moodle structure of that page, and they kept asking about how to upload a file.

\section{2) Teachers'perspectives}

Teachers were required to perform the following tasks, upload assignment, upload a lecture, modify weekly plan, and make a quiz in Moodle while each had further sub-tasks. After accomplishing each task they were required to respond on providing a task based questionnaire. Only 4 teachers from U1 and 6 from $\mathrm{U} 2$ responded back the questionnaire - a total of 10 responses were received from teachers (Table 4.48). Nielsen [30] stated that testing five users is typically enough for evaluating design, most importantly the usability problems. Hence, we considered this size enough to find out teachers' problems about navigation design of Moodle. Figure 6 represents the experience of teachers with the use of Moodle.

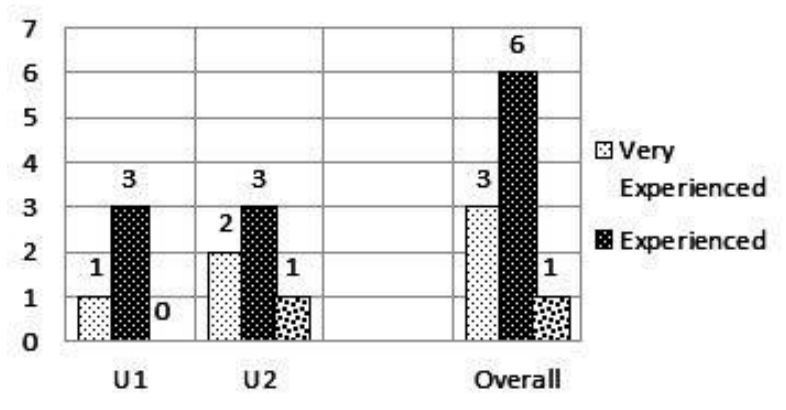

Fig. 6. Experince of using Moodle (Teachers)

\section{a) Task One: Upload an assignment}

Results: In response of Q1 teachers at U1 responded as neutral, but teachers at U2 agreed that they needed help to upload an assignment. In Q2 it was easy for teachers of U2 to set assignment submission type as "Online text", however, teachers of U1 teachers remained neutral. For Q3, description of links in performing this task presented desired meaning to teachers at both universities. Pertaining to Q4, teachers found that minimum steps were required to upload an assignment (TABLE XVI).

TABLE XVI. RESPONSES ON TASK ONE

\begin{tabular}{|c|ccccc|ccccc|ccccc|}
\hline Q\# & \multicolumn{5}{|c|}{ U1 } & \multicolumn{5}{|c|}{ U2 } & \multicolumn{5}{|c|}{ TOTAL } \\
\cline { 2 - 6 } & SA & A & N & D & SD & SA & A & N & D & SD & SA & A & N & D & SD \\
\hline Q1 & 1 & 2 & 1 & 0 & 0 & 1 & 3 & 0 & 1 & 1 & 2 & 5 & 1 & 1 & 1 \\
\hline Q2 & 1 & 0 & 2 & 1 & 0 & 0 & 4 & 0 & 1 & 1 & 1 & 4 & 2 & 2 & 1 \\
\hline Q3 & 1 & 2 & 1 & 0 & 0 & 1 & 3 & 2 & 0 & 0 & 2 & 5 & 3 & 0 & 0 \\
\hline Q4 & 0 & 2 & 2 & 0 & 0 & 1 & 3 & 2 & 0 & 0 & 1 & 5 & 4 & 0 & 0 \\
\hline
\end{tabular}

$\mathrm{SA}=$ strongly agree, $\mathrm{A}=$ agree, $\mathrm{N}=$ neutral, $\mathrm{D}=$ disagree, $\mathrm{SD}=$ strongly disagree

\section{b) Task Two: Upload a Lecture}

Results: For Q1, teachers reported that they were able to attach multiple files at a time. For Q2, teachers at U1 agreed that label of buttons showed the desired destination. In case of teachers of U2, equal number of teachers were agreed and neutral. For Q3, teachers of U1 easily found how to hide a file, while at $\mathrm{U} 2$, equal number of teachers agreed and disagreed that they found the option for hiding the file easily. While for Q4, teachers at both universities reported that they easily renamed the file. Lastly, for Q5, links/selection presented desired meaning to teachers of both universities (TABLE XVII).

TABLE XVII. RESPONSES ON TASK TWO

\begin{tabular}{|c|l|llll|lllll|lllll|l|}
\hline \multirow{2}{*}{ Q\# } & U1 & SA & A & N & D & SD & SA & A & N & D & SD & SA & A & N & D & SD \\
\hline Q1 & 0 & 1 & 1 & 2 & 0 & 0 & 4 & 1 & 1 & 0 & 0 & 5 & 2 & 3 & 0 \\
\hline Q2 & 0 & 2 & 2 & 0 & 0 & 1 & 4 & 0 & 1 & 0 & 1 & 6 & 2 & 1 & 0 \\
\hline Q3 & 0 & 1 & 1 & 2 & 0 & 0 & 4 & 1 & 1 & 0 & 0 & 5 & 2 & 3 & 0 \\
\hline Q4 & 0 & 2 & 2 & 0 & 0 & 0 & 3 & 2 & 1 & 0 & 0 & 5 & 4 & 1 & 0 \\
\hline Q5 & 1 & 2 & 1 & 0 & 0 & 2 & 2 & 1 & 1 & 0 & 3 & 4 & 2 & 1 & 0 \\
\hline SA = strongly agree, A = agree, N = neutral, & D = disagree, & SD $=$ \\
strongly disagree
\end{tabular}

c) Task Three: Modify weekly plan

Results: Result of this task shows that teachers at both universities easily found delete option as a response to Q1. For Q2, 2 teachers of U1 disagreed that links/ icons presented desired meaning to them, and teachers of U2 remained neutral. Pertaining to Q3, most teachers of both universities reported that they were not able to modify weekly plans and needed help. For Q4, 2 out of 4 teachers at U1 remained neutral, while at U2, teachers found it easy to hide a week. For Q5, most teachers at both universities agreed that the current week is highlighted. Pertaining to Q6, teachers of both universities 
responded that they were unable to expand and collapse weekly plan. For Q7 teachers of both universities remained neutral and reported that very often they remember that they need to click "Turn editing on" button in order to add/modify course elements (TABLE XVIII).

TABLE XVIII. RESPONSES ON TASK THREE

\begin{tabular}{|c|c|c|c|c|c|c|c|c|c|c|c|c|c|c|}
\hline \multirow{2}{*}{$\# \quad$ Q } & \multicolumn{4}{|c|}{ U1 } & \multicolumn{5}{|c|}{$\mathrm{U} 2$} & \multicolumn{5}{|c|}{ TOTAL } \\
\hline & & $\mathrm{A}$ & $\overline{\mathrm{N}}$ & $\overline{\mathrm{SI}}$ & $\overline{\mathrm{SA}}$ & $\overline{\mathrm{A}}$ & $\mathrm{N}$ & $\mathrm{D}$ & & SA & $\mathrm{A}$ & $\bar{N}$ & & \\
\hline Q1 & 0 & 3 & 1 & 0 & 1 & 3 & 1 & 1 & 0 & & 6 & 2 & & 0 \\
\hline Q2 & 0 & 1 & 12 & $\overline{0}$ & 0 & 1 & 3 & 2 & 0 & 0 & 2 & $T$ & & $\overline{0}$ \\
\hline Q3 & 0 & 2 & 11 & 0 & 0 & 4 & 1 & 1 & 0 & 0 & 6 & 2 & & $\overline{0}$ \\
\hline Q4 & 0 & 12 & 2 & 0 & 1 & 3 & 2 & 0 & 0 & 1 & 4 & 4 & 1 & 0 \\
\hline Q5 & 0 & 3 & $\overline{0}$ & . & 0 & 4 & 2 & 0 & 0 & 0 & 7 & 2 & 1 & 0 \\
\hline Q6 & 0 & 0 & 13 & 0 & 0 & 0 & 2 & 4 & 0 & 0 & 0 & 3 & 7 & 0 \\
\hline Q7 & 0 & 0 & 31 & & 0 & 1 & 3 & 2 & 0 & 0 & 1 & 6 & 3 & 0 \\
\hline
\end{tabular}

$\mathrm{SA}=$ strongly agree, $\mathrm{A}=$ agree, $\mathrm{N}=$ neutral, $\mathrm{D}=$ disagree, $\mathrm{SD}=$ strongly disagree

d) Task Four: Make a quiz

Results: Responses on Q1 were as teachers of U1 disagreed that they feel it simple to make a quiz in Moodle while at $\mathrm{U} 2$, teachers reported that it is easy to make a quiz in Moodle. For Q2, at U1, equal number of responses received on agreed and neutral that link/button's text helped in recognizing how to add quiz in Moodle. Whereas, at U2, teachers agreed with this question. For Q3, teachers of U1 disagreed that there are certain confusing link descriptions. While teachers of $\mathrm{U} 2$ faced some confusing link descriptions. For Q4, equal number of teachers at U1 agreed and remained neutral, whereas at U2, teachers agreed that there are many steps to make a quiz which can be eliminated. For last question that is Q5, teachers of U1 reported that they needed help to add a quiz in Moodle while at U2 teachers agreed that they required help to add a quiz in Moodle (TABLE XIX).

TABLE XIX. RESPONSES ON TASK FOUR

\begin{tabular}{|c|l|llll|llllll|lllll|l|}
\hline \multirow{2}{*}{ Q\# } & U1 & U2 & U2 & SA & N & D & SD & SA & A & N & D & SD & SA & A & N & D & SD \\
\hline Q1 & 0 & 0 & 1 & 3 & 0 & 1 & 1 & 0 & 3 & 1 & 1 & 1 & 1 & 6 & 1 \\
\hline Q2 & 0 & 3 & 1 & 0 & 0 & 3 & 3 & 0 & 0 & 0 & 3 & 6 & 1 & 0 & 0 \\
\hline Q3 & 0 & 2 & 2 & 0 & 0 & 0 & 3 & 0 & 3 & 0 & 0 & 5 & 2 & 3 & 0 \\
\hline Q4 & 1 & 2 & 1 & 0 & 0 & 1 & 4 & 1 & 0 & 0 & 2 & 6 & 2 & 0 & 0 \\
\hline Q5 & 0 & 3 & 0 & 1 & 0 & 0 & 5 & 1 & 0 & 0 & 0 & 8 & 1 & 1 & 0 \\
\hline
\end{tabular}

$\mathrm{SA}=$ strongly agree, $\mathrm{A}=$ agree, $\mathrm{N}=$ neutral, $\mathrm{D}=$ disagree, $\mathrm{SD}=$ strongly disagree

After accomplishing all the tasks, teachers were asked to rate the level of difficulty in accomplishing each task, and the results indicate that the majority of teachers reported that they found it easy to perform tasks one, two, and three. However, task four which was related to the creation of a quiz was difficult and required help.
TABLE XX. LEVEl OF DifficUlty IN PERForming EACH TASK

\begin{tabular}{|c|ccccc|cccccc|cccc|}
\hline \multirow{2}{*}{ Q\# } & \multicolumn{5}{|c|}{ U1 } & \multicolumn{5}{|c|}{ U2 } & \multicolumn{5}{|c|}{ TOTAL } \\
\cline { 2 - 5 } & VE & E & N & D & VD & VE & E & N & D & VD & VE & E & N & D & VD \\
\hline Q1 & 12 & 42 & 16 & 2 & 0 & 10 & 33 & 21 & 1 & 3 & 22 & 75 & 37 & 3 & 3 \\
\hline Q2 & 21 & 35 & 15 & 1 & 0 & 17 & 29 & 15 & 4 & 3 & 38 & 64 & 30 & 5 & 3 \\
\hline Q3 & 14 & 31 & 18 & 7 & 2 & 13 & 30 & 16 & 6 & 3 & 27 & 61 & 34 & 13 & 5 \\
\hline Q4 & 17 & 34 & 20 & 1 & 0 & 15 & 30 & 19 & 3 & 1 & 32 & 64 & 39 & 4 & 1 \\
\hline
\end{tabular}

$\mathrm{VE}=$ very easy, $\mathrm{E}=$ easy, $\mathrm{N}=$ neutral, $\mathrm{D}=$ difficult, $\mathrm{VD}=$ very difficult

\section{Results of correlation}

To answer the hypotheses $\mathrm{H} 1$ and $\mathrm{H} 2$, we performed Pearson correlation analysis. For correlation tests responses of both universities were collectively analyzed. The purpose of $\mathrm{H} 1$ is to find out whether ease of navigation correlates with satisfaction about navigation design and efficiency of performing task Results (TABLE XXI) indicate that ease of navigation has a significant relationship with satisfaction about navigation design i.e. 0.803 and efficiency of completing the task i.e. 0.989. It means, if a user perceives ease of navigation, it increases the user's satisfaction about navigation design.

TABLE XXI. CORRELATION OF EASE OF NAVIGATION WITH SATISFACTION About NAVIGATION DESIGN AND EFFICIENCY OF PERForming THE TASKS

\begin{tabular}{|c|l|l|}
\hline Factors & $\begin{array}{l}\text { Satisfaction about } \\
\text { Navigation Design }\end{array}$ & $\begin{array}{l}\text { Efficiency of Performing } \\
\text { Task }\end{array}$ \\
\hline Ease of Navigation & 0.803 & 0.989 \\
\hline
\end{tabular}

TABLE XXII presents the result of H2. The purpose of $\mathrm{H} 2$ is to check whether seven factors of the framework are correlated to ease of navigation experience and satisfaction about navigation design. Result of correlation confirms the positive relationship of all navigation factors with ease of navigation and satisfaction about navigation design. The result shows that links are significantly correlated with ease of navigation and satisfaction about navigation design. It means that if link appearance indicates that it is clickable and text of the link is related to visitors of the page, it will have a positive effect on ease of navigation and satisfaction about navigation design. The menu is also positively correlated with ease of navigation and satisfaction about navigation design having values 0.719 and 0.862 respectively, indicating that if users perceive that items in a menu are arranged logically, it enhances their ease of navigation experience and satisfaction on navigation design. Moreover, result in table shows that all other variables such as navigation aids, shortcuts facility, services facility, adaptive navigation support, and consistency are also strongly correlated with ease of navigation and satisfaction about navigation design.

TABLE XXII. CORRELATION OF NAVIGATION FACTORS WITH EASE OF NAVIGATION AND Satisfaction About NAVIGATION DESIGN

\begin{tabular}{|l|c|c|}
\hline Factors & $\begin{array}{l}\text { Ease of } \\
\text { Navigation }\end{array}$ & $\begin{array}{l}\text { Satisfaction about } \\
\text { Navigation Design }\end{array}$ \\
\hline Links & 0.984 & 0.801 \\
\hline Menus & 0.719 & 0.862 \\
\hline
\end{tabular}




\begin{tabular}{|l|c|c|}
\hline & & \\
\hline Navigation Aids & 0.867 & 0.826 \\
\hline Shortcuts & 0.967 & 0.726 \\
\hline Services & 0.870 & 0.820 \\
\hline Adaptive Navigation Support & 0.785 & 0.886 \\
\hline Consistency & 0.839 & 0.861 \\
\hline
\end{tabular}

\section{CONCLUSIONS AND FUTURE WORK}

Moodle is selected for evaluation in order to explore whether it contains all navigational factors of proposed navigational evaluation framework for LMS or how well these are maintained in Moodle. Surveys result revealed that Moodle does not include some navigational factors and those are implemented requiring improvements. The navigation factors of proposed framework that are not provided in Moodle are back to top link, site map, proper help and documentation, powerful search function, and shortcut key facility. In addition, there are no highlighting techniques implemented in Moodle, which can direct the users to important information or events. These are all essentials for an efficient navigation. Furthermore, customizability is also an important aspect of good navigation, but Moodle still does not allow users to customize pages/courses according to their need and preference. Some of the users are not satisfied that links are still visible to them even though these are not relevant to them.

Moreover, some of the problems encountered in the navigation design of Moodle are inconsistency in color and placement of buttons on different pages, presence of back page button on some pages but on some pages there is no back page button, there is no strategy by which users can differentiate visited and not-visited links, some of the icons are not understandable just by looking at them and there is no supporting text that help understanding the desired meaning of icons, unnecessary options are available in navigation block (menu), menu items change when moving to a new page, for some users organization of items in navigation block does not seem logical that is rarely required items are placed at the top.

Navigation of LMSs has great influence on learning and teaching processes. If navigation of such systems is not efficient it can distract students from actual learning because they will spend most of the time in learning how to use the system. Also, if LMSs hinder navigation, teachers will be spending most of the time in trying to understand the system and giving less time for teaching activities, since they would have already been frustrating in understanding the way systems works. Hence, in order to overcome these obstacles a proper navigation structure should be maintained to enhance learning and teaching activities. By doing this, we are making the users' satisfied and increasing their experience of using LMS.

Furthermore, results of correlation showed that ease of navigation is positively correlated with the factors of proposed framework. Also, correlation result indicated that ease of navigation is positively correlated with efficiency of achieving goals. It means users feel ease of navigation and it increases their efficiency of achieving the goal quickly.

In this research, we had insufficient sample size of teachers to reach some reliable results in perspective of teachers. Moreover, our sample set only included students from strong IT background. In future, we aim to increase target sample size in which respondents from business, law, environmental sciences and from some other disciplines will be included. In addition, sample size of teachers will be increased in future research. In future, further, we plan to investigate: Moodle's navigation structure in comparison to other open source LMSs based on proposed framework; and how different users' groups based on gender, age, educational background, and computer proficiency, perceive navigation in LMS.

\section{REFERENCES}

[1] S. Kim and M. Lee, "Validation of an evaluation model for learning management systems," J. Comput. Assist. Learn., vol. 24, no. 4, pp. 284-294, 2008.

[2] S. Minocha and H. Sharp, "Learner-Centred Design and Evaluation of Web-Based E-Learning Environments" in The 7th HCI Educators Workshop: Effective Teaching and Training in HCI,University of Central Lancashire, Preston.1-2 April, 2004.

[3] Y. Hammouche, "The Usability Testing of Optima Learning Management System - From Student Interface," Turku University of Applied Sciences, 2014.

[4] P. Zaharias, "A usability evaluation method for e-learning," in CHI '06 extended abstracts on Human factors in computing systems - CHI '06, 2006, no. January 2006, p. 1571.

[5] P. Zaharias and A. Poylymenakou, "Developing a Usability Evaluation Method for e-Learning Applications: Beyond Functional Usability," Int. J. Hum. Comput. Interact., vol. 25, no. 1, pp. 75-98, 2009.

[6] A. Shahzad, W. Hafizi, and A. G. Golamdin, "E-Learning Navigation Model Based on Student 's Learning Behavior : Case Study in UUM," Int. J. Bus. Soc. Sci., vol. 5, no. 5, pp. 118-130, 2014.

[7] A. M. Reina, "Separating the Navigational Aspect," in Proc. 2nd Int'1 Workshop on Aspect Oriented Programming for Distributed Computing Systems (ICDCS-2002), Vol. 2, 2002.

[8] E. Zakaria and M. Y. Daud, "The Role of Technology: Moodle as a Teaching Tool in a Graduate Mathematics Education Course," Asian J. Manag. Sci. Educ., vol. 2, no. 4, pp. 46-52, 2013.

[9] J. Nielsen, "Usability 101: Introduction to Usability," Nielsen Norman Group, 2012. [Online]. Available: http://www.nngroup.com/articles/how-to-rate-the-severity-of-usabilityproblems/. [Accessed: 04-Aug-2015].

[10] "Usability", Wikipedia. [Online]. Available: https://en.wikipedia.org/wiki/Usability. [Accessed: 02-Jun-2015].

[11] A. Inversini, L. Botturi, and L. Triacca, "Evaluating LMS Usability for Enhanced eLearning Experience," Ed-Media 2006, pp. 595-601, 2006.

[12] Y. Wang, H. Wang, W. Huang, and Y. Jiao, "Implementing a web-based personalized learning and assessment system," ICCSE 2010 - 5th Int. Conf. Comput. Sci. Educ. Final Progr. B. Abstr., pp. 1629-1632, 2010.

[13] J. Reyna, "Developing quality e-learning sites : A designer approach," New York, pp. 837-838, 2009.

[14] "Why you must free up navigation in e-learning." [Online]. Available: http://info.shiftelearning.com/blog/bid/241958/3-Reasons-Why-YouMust-Free-Up Navigation-In-eLearning. [Accessed: 6-Jun-2015].

[15] C. McKnight, J. Richardson, and A. Dillon, "Hypertext: a psychological perspective," Ellis Horwood Series in Interactive Information Systems Published by Ellis Horwood. 1993.

[16] J. Melton, "The lms moodle: A usability evaluation," Prefect. Univ. Kumamoto Retrieved ..., pp. 1-24, 2006. 
[17] G. Kakasevski, "Evaluating usability in learning management system Moodle." Information Technology Interfaces, 30th International Conference on. IEEE, 2008.

[18] M. Ivanović, Z. Putnik, Ž. Komlenov, T. Welzer, M. Hölbl, and T. Schweighofer, "Usability and privacy aspects of moodle: Students' and teachers' perspective," Inform., vol. 37, no. 3, pp. 221-230, 2013.

[19] M. A. Amaral and C. M. De Almeida, "Usability Assessment in Moodle Abstract : 2 E-learning and Usability," vol. 1, no. 10, pp. 1-10, 2009.

[20] "LMS Usability Evaluation Report," Prepared by the LMS Usability Working Group, 2010.

[21] I. Padayachee, P. Kotzé, and A. van der Merwe, "Course Management Systems from a Usability Perspective," Alternation, vol. 18, no. 1, pp. $297-317,2011$.

[22] L. Martin, D. R. Martínez, O. Revilla, M. José, O. C. Santos, and J. G. Boticario, "Usability in e-Learning Platforms : heuristics comparison between Moodle, Sakai and dotLRN," Artif. Intell., vol. 509, no. Lll, pp. 75-84, 2003.

[23] D. Zub and E. Eessaar, "Technological Developments in Education and Automation," 2010
[24] J. Rosato, C. Dodds, and S. Laughlin, "Usability of Course Management Systems by Students," Methods.

[25] M. Machado and E. Tao, "Blackboard vs. Moodle: Comparing user experience of learning management systems," Proc. - Front. Educ. Conf. FIE, no. December 2006, pp. 7-12, 2007.

[26] H. Baytiyeh, "Work in progress; Open source usability evaluation: The case of Moodle," 2011 Front. Educ. Conf., pp. F4E-1-F4E-2, 2011.

[27] W. Gate and R. Heights, "A usability study of moodle," no. 2007, pp. 60-84, 2013

[28] A. Seffah, T. Mohamed, H. Habieb-mammar, and A. Abran, "The Journal of Systems and Software Reconciling usability and interactive system architecture using patterns," vol. 81, pp. 1845-1852, 2008.

[29] A. Oztekin, Z. James, and O. Uysal, "International Journal of Industrial Ergonomics UseLearn: A novel checklist and usability evaluation method for eLearning systems by criticality metric analysis," Int. J. Ind. Ergon., vol. 40, no. 4, pp. 455-469, 2010.

[30] "Usability 101: Introduction to Usability." [Online]. Available: http://www.nngroup.com/articles/usability-101-introduction-tousability/. [Accessed: 1-Oct-2015]. 